\title{
UPAYA MENINGKATKAN HASIL BELAJAR MAHASISWA PADA MATA KULIAH TEKNOLOGI INFORMASI DAN KOMUNIKASI (TIK) MELALUI TUTOR SEBAYA DI JURUSAN PENDIDIKAN GEOGRAFI
}

\author{
Mahara Sintong, Darwin P. Lubis, Mbina Pinem \\ Dosen Jurusan Pendidikan Geografi, Fakultas IImu Sosial, Universitas Negeri Medan \\ Email: hara.tampubolon@yahoo.com
}

\begin{abstract}
Abtsrak
Mata kuliah Teknologi Informasi dan Komunikasi (selanjutnya disingkat mata pelajaran TIK yang dulunya bernama mata kuliah komputer, merupakan salah satu mata kuliah di Semester I (satu) yang ditetapkan di Jurusan Pendidikan Geografi. Mata kuliah ini terfokus pada pencapaian kompetensi mahasiswa dalam pengetahuan dasar tentang pengoperasian microsoft office : word, excel, powerpoint dan internet yang dapat mendukung mahasiswa dalam penyelesain pelaporan tugas dan meteri presentase kuliah. Substansi mata kuliah ini menekankan pada peningkatan kemampuan mahasiswa untuk mempersiapkan laporan, tugas, serta materi presentase, penggunaan internet sebagai media informasi dan sumber belajar, pengiriman surat melalui email serta komunikasi dengan chatting menggunakan fasilitas messenger. Secara garis besar ini dititik beratkan pada praktikum langsung menggunakan komputer. Dimulai dari pengenalan tools atau fungsi-fungsi yang terdapat pada masingmasing perangkat lunak, hingga akhirnya mahasiswa dapat meningkatkan pengetahuannya dalam bidang teknologi khususnya komputer. Beberapa faktor yang mempengaruhi rendahnya nilai hasil perkuliahan TIKadalah : Pertama masalah fasilitas perkuliahan. Pada setiap pembelajaran aplikasidengan menggunakan komputer dan internetyang menjadi salah satu materi dasar mata kuliah dilaksanakan di ruang komputer dengan jumlah yang tidak memadai. Materi disampaikan dengan cara membagi dua kelompok mahasiswa, hal ini dilakukan karena jumlah komputer tidak mencukupi untuk seluruh mahasiswa yang berjumlah 31 orang. Komputer yang ada berkisar 25 unit di Jurusan Pendidikan Geografi.Kedua, perlunya perubahan paradigma mengajar. Keberhasilan mahasiswa dalam kuliah dipengaruhi oleh beberapa faktor, salah satunya adalah metode yang digunakan dosen dalam mengajar. Pada kenyataannya dalam perkuliahan masih menggunakan metode konvensional.Tujuan kegiatanpenelitian ini adalah untuk mengetahui kemampuan hasilbelajar mahasiswa dengan penggunaan metode pembelajaran konvensional dan implementasi metode pembelajaran tutor sebaya dapat meningkatkan motivasi mahasiswa dalam belajar dalam pelaksanaan mata kuliah TIK. Adanya peningkatan prestasi belajar mahasiswa adalah mulai dari kemampuan awal mahasiswa hanya 49,27 \% yang dinyatakan lulus, setelah dilakukan inovasi pembelajaran dengan menggunakan model pembelajaran Tutor sebaya dan praktek lapangan maka seluruh mahasiswa dinyatakan lulus.
\end{abstract}

Kata kunci: Hasil belajar, TIK, tutor sebaya

\section{PENDAHULUAN}

Mata kuliah Teknologi Informasi dan Komunikasi (selanjutnya disingkat mata kuliah TIK) yang dulunya bernama mata kuliah komputer, merupakan salah satu mata kuliah yang ditetapkan di Jurusan Pendidikan Geografi) yang bertujuan mempersiapkan mahasiswa untuk mengantisipasi dampak perkembangan teknologi khususnya bidang ilmu geografi dalam kehidupan sehari-hari. Konsekuensi dari ketetapan tersebut, jurusan pendidikan geografi telah menyediakan perangkat pendukung, 
diantaranya yang terdiri dari laboratorium komputer yang sesuai dengan kebutuhan belajar mahasiswa dan dosen yang memiliki kemampuan akademik dan profesional dalam membelajarkan mahasiswanya.

Matakuliah TIK dalam Kurikulum Berbasis Kompetensi (KBK) yang diterapkan di Jurusan Pendidikan Geografi FIS Unimed merupakan matakuliah wajib pada Semester ganjil, tepatnya pada semester I (satu).Matakuliah TIK ini termasuk kelompok Matakuliah Keilmuan dan Keterampilan (MKK), yaitu kelompok bahan kajian dan pembelajaraan yang ditujukan terutama untuk memberikan landasan penguasaan ilmu dan keterampilan tertentu. Matakuliah Keilmuan dan Keterampilan (MKK) ini dapat dijabarkan sebagai matakuliah yang berisi bahan-bahan keilmuan yang akan ditransfer sesuai bidang masing-masing.

Bahan kajian dan materi yang disajikan dalam matakuliah TIK didasarkan atas aktivitas yang dilakukan pada pembelajaran. Mata kuliah ini terfokus pada pencapaian kompetensimahasiswa dalam pengetahuan dasar tentangpengoperasian microsoft office : word, excel, powerpoint dan internet yang dapat mendukung mahasiswa dalam penyelesain pelaporan tugas dan meteri presentase kuliah. Substansi mata kuliah ini menekankan pada peningkatan kemampuan mahasiswa untuk mempersiapkan laporan, tugas, serta materi presentase, penggunaan internet sebagai media informasi dan sumber belajar, pengiriman surat melalui email serta komunikasi dengan chatting menggunakan fasilitas messenger. Secara garis besar ini dititik beratkan pada praktikum langsung menggunakan komputer. Dimulai dari pengenalan tools atau fungsi-fungsi yang terdapat pada masing-masing perangkat lunak, Bila digambarkan bahan kajian pada matakuliah TIK pada jenjang pembelajaran, disajikan pada bagan berikut:

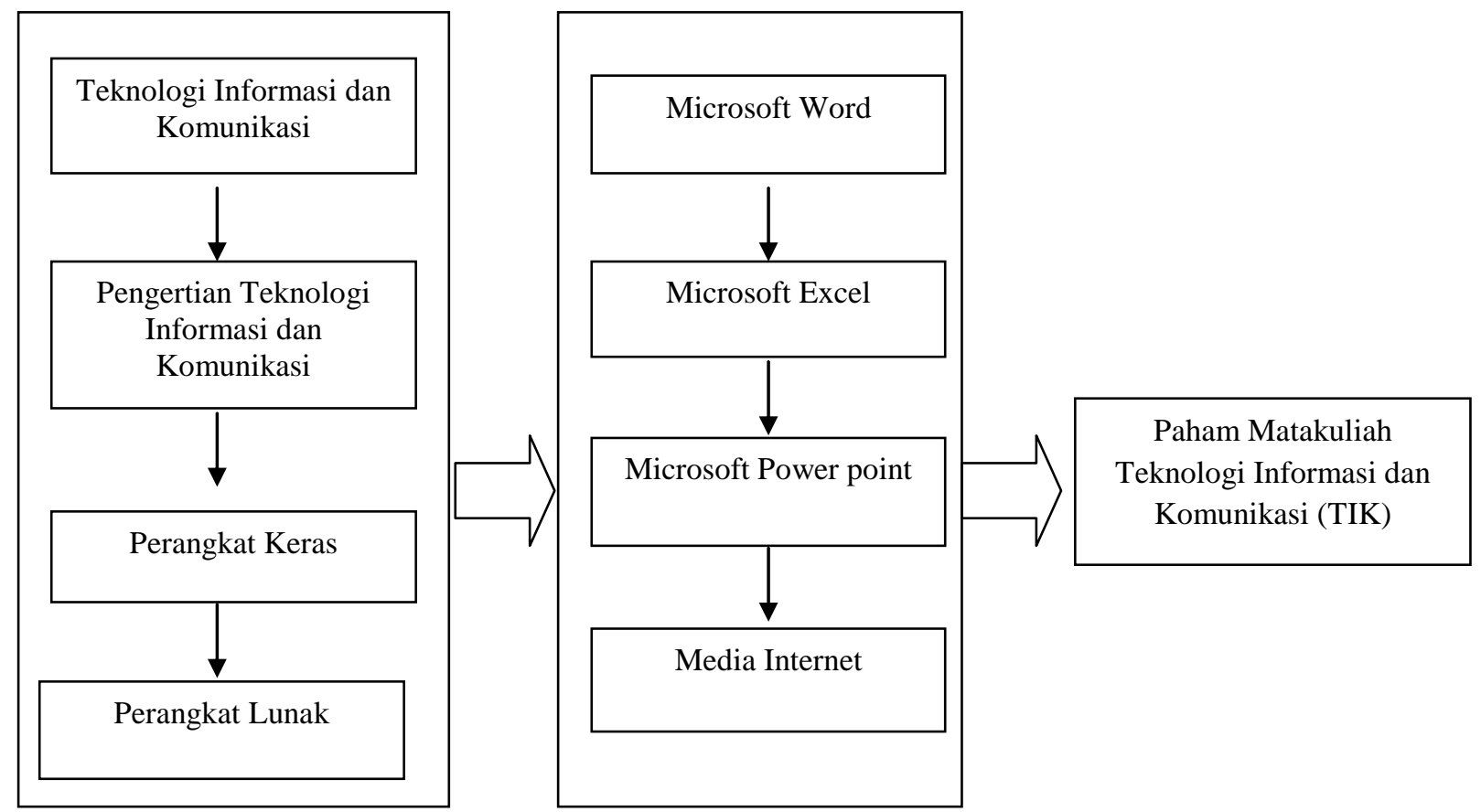

Gambar 1. Bahan Kajian Pada Matakuliah TIK

Hasil pembelajaran pada matakuliah TIK adalah mahasiswa memiliki kompetensi berupa kemampuan:

1. Mengoperasikan microsoft word
2. Menganalisis perhitungan dengan menggunakan microsoft excel

3. Membuat materi dengan menggunakan microsoft powerpoint 
4. Mengetahui cara menggunakan internet untuk mencari materimateri yang dibutuhkan dalam mendukung perkuliahan

Beberapa faktor yang mempengaruhi rendahnya nilai hasil perkuliahan TIKadalah :Pertama masalah fasilitas perkuliahan. Materi disampaikan dengan cara membagi dua kelompok mahasiswa, hal ini dilakukan karena jumlah komputer tidak mencukupi untuk seluruh mahasiswa yang berjumlah 29 orang. Komputer yang ada berkisar 25 unit di Jurusan Pendidikan Geografi.Kedua, perlunya perubahan paradigma mengajar. Keberhasilan mahasiswa dalam kuliah dipengaruhi oleh beberapa faktor, salah satunya adalah metode yang digunakan dosen dalam mengajar.

Tujuan Penelitian ini adalah untuk mengetahui: (1) Kemampuan hasil belajar mahasiswa dengan penggunaan metode pembelajaran konvensional; Implementasi metode pembelajaran tutor sebaya dapat meningkatkan motivasi mahasiswa dalam belajar dalam pelaksanaan mata kuliah TIK.

\section{METODE PENELITIAN}

Langkah-langkah penelitian tindakan kelas dilakukan dalam beberapa siklus yang tiap siklusnya terdiri dari empat tahap sebagai berikut yaitu perencanaan, pelaksanaan, pengamatan dan refleksi.

\section{Pelaksanaan Mekanisme dan Rancangan}

Adapun langkah-langkah dalam pelaksanaan kegiatan penelitian ini dilakukan melalui beberapa tahapan :

\section{Siklus I}

a. Tahap Persiapan

1) Dosen pengampu mata kuliah (peneliti) mempersiapkan unsur materi pembelajaran atau perangkat pembelajaran antara lain RPS dan Kontrak Perkuliahan.

2) Dosen memberikan petunjuk tugas kepada mahasiswa untuk mencari informasi sebanyak-sebanyaknya melalui media melalui internet.
3) Selanjutnya dosen pengampu (peneliti) mempersiapkan peralatan penelitian demikian halnya dengan mahasiswa ditugaskan mencari bahan bacaan yang berkaitan dengan mata kuliah tersebut.

4) Dosen menjelaskan prosedur/sistimatika yang dilakukan pada matakuliah TIK.

5) Pada tahap persiapan disusun jadwal dan pembagian kerja bagi tim dosen matakuliah TIK persiapan dilakukan pada awal bulan Agustus 2017.

b. Tahap Pelaksanaan Kegiatan

1) Mahasiswa dibagi menjadi 6 kelompok.

2) Setiap kelompok mempersiapkan bahan pendukung kegiatan praktek TIK.

3) Dosen pengampu (Tim Peneliti) mengarahkan jalannya praktek TIK.

4) Mahasiswa diberikan kesempatan untuk melakukan praktek di Laboratorum komputer.

c. Pengamatan/ Observasi tindakan

Pada tahap ini dosen pengampu mata kuliah (timpeneliti) mencermati mahasiswa Jurusan Pendidikan Geografi yang sedang mengikuti proses kerja kelompok. Penelitian dilakukan dengan cara melakukan pengamatan mahasiswa yang aktif bekerjasama dalam kelompok melakukan praktik di laboratorium komputer.

\section{d. Refleksi Tindakan}

Setelah tahapan pelaksanaan selesai maka dilanjutkan dengan mengevaluasi hasil pengamatan sementara dilapangan melalui forum diskusi yang diisi oleh kelompok untuk mengetahui capaian indikator keberhasilannya dan hambatan yang dialami.

Dari Pelaksanaan Pada Siklus I dapat aspek yang dinilai dan kriteria penilaiannya dapat dilihat pada Tabel 1. 
Tabel 1. Penilaian Persiapan dan Pelaksanaan Praktik Siklus I

\begin{tabular}{|c|c|l|c|}
\hline \multirow{2}{*}{$S$} & $\begin{array}{c}\text { Nomor } \\
\text { Kode } \\
\text { Penilaian }\end{array}$ & \multicolumn{1}{|c|}{ Aspek yang dinilai dan kriteria penilaian } & Penilaian \\
\cline { 2 - 4 } K & 1 & Penguasaan materi kuliah TIK & $60-100$ \\
\cline { 2 - 4 } L & 2 & Penguasaan software Microsoft Word & $60-100$ \\
\cline { 2 - 4 } U & 3 & Penguasaan software Microsoft Excel & $60-100$ \\
\cline { 2 - 4 } S & 4 & Penguasaan software Microsoft Power Point & $60-100$ \\
\cline { 2 - 4 } & 5 & Kerjasama kelompok/pembagian peran dalam kelompok & $60-100$ \\
\cline { 2 - 4 } I & 6 & $\begin{array}{l}\text { Memahami rencana penelitian yang dituangkan pada } \\
\text { praktek laboratorium komputer }\end{array}$ & $60-100$ \\
\cline { 2 - 4 } & \multicolumn{1}{|c|}{ Rata-rata Penilaian } & $60-100$ \\
\hline
\end{tabular}

Sumber : Dosen Pengampu Matakuliah TIK

\section{Siklus II}

a. Tahap Persiapan

Dosen Pengampu (Tim Peneliti) membuat rencana pembelajaran berdasarkan hasil refleksi pada siklus pertama.Selanjutnya mempersiapkan administrasi mahasiswa melakukan studi pustaka dan pencarian informasi di internet, jurnal dan buku.

b. Tahap Pelaksanaan Kegiatan

1. Mengamati interaksi belajar yang sedang berlangsung (aktifitas, kreatifitas untuk mahasiswa yang menjadi tutor maupun sebagai teman

2. Perwakilan kelompok mahasiswa (tutor) melakukan pengamatan pekerjaan sesama temannya

3. Selanjutnya, kelompok mahasiswa melakukan uji coba mengolah kata dan data dengan menggunakan komputer

4. Setelah itu melakukan pretsentasi dengan menggunakan powerpoint
5. Selanjutnya, melakukan lay-out dan mencetak hasil presentasi.

c. Pengamatan/ Observasi tindakan

Pada tahap ini dosen pengampu mata kuliah (Tim Peneliti) mencermati mahasiswa Jurusan Pendidikan Geografi yang sedang mengikuti proses identifikasi di laboratorium. Data yang dikumpulkan dalam tahap pengamatan ini dijadikan sebagai data kualitatif dengan indikator keaktifan dalam pembelajaran menyelesaikan masalah yang diperoleh dari hasil praktik lapangan.

d. Refleksi Tindakan

Tim Peneliti melakukan refleksi terhadap pelaksanaan siklus kedua dan menyusun rencana untuk siklus ketiga.

Pada Siklus II dapat diperoleh aspek yang dinilai dan kriteria penilainnya dapat dilihat pada tabel dibawah ini :

Tabel 2. Penilaian Persiapan dan Pelaksanaan Praktik Siklus II

\begin{tabular}{|c|c|c|c|}
\hline $\mathrm{S}$ & No. kode & Aspek yang dinilai dan kriteria penilaian & Penilaian \\
$\mathrm{I}$ & penilaian & Penguasaan prosedur kerja identifikasi & $60-100$ \\
\cline { 2 - 4 } & 1 & Pen &
\end{tabular}




\begin{tabular}{|c|c|c|c|}
\hline \multirow{3}{*}{$\begin{array}{l}L \\
U \\
S\end{array}$} & 2 & Penguasaan software Microsoft Word & $60-100$ \\
\hline & & Penguasaan software Microsoft Excel & $60-100$ \\
\hline & 3 & Penguasaan software Microsoft Power Point & $60-100$ \\
\hline \multirow{3}{*}{ II } & 4 & Sistimatika pembuatan laporan & $60-100$ \\
\hline & 5 & $\begin{array}{l}\text { Kerjasama kelompok/Pembagian peran dalam } \\
\text { kelompok }\end{array}$ & $60-100$ \\
\hline & & Rata-rata Penilaian & $60-100$ \\
\hline
\end{tabular}

Sumber : Dosen Pengampu Matakuliah TIK

Penelitian ini dilaksanakan di Jurusan Pendidikan Geografi Fakultas Ilmu Sosial Universitas Negeri Medan Adapun waktu pelaksanaan dilakukan selama 5 bulan ( Agustus - November 2017). Penelitian dilakukan dengan penelitian tindakan kelas (PTK) dan sebagai subyek penelitian adalah mahasiswa Jurusan Pendidikan Geografi yang sedang mengambil/mengikuti mata kuliah TIK.pada semester ganjil. Tim peneliti adalah dosen pengampu mata kuliah Teknologi Informasi dan Komunikasi (TIK), dalam hal ini tim peneliti melihat dan mengukur sejauh mana kemampuan mahasiswa dalam menyelasaikan masalah yang diperoleh dari praktek dilaboratorium, selanjutnya Dosen/Tim Peneliti membuat metode pembelajaran melalui suatu rancangan model dalam pembelajaran.

\section{Teknik Pengumpulan Data}

1) Tes: dipergunakan untuk mendapatkan data tentang hasil belajar mahasiswa. Test dilakukan dengan menilai kemampuan mahasiswa memahami teori komputer., menilai kemampuan mahasiswa melakukan praktek komputer

2) Observasi

Observasi (pengamatan) dilakukan dengan cara observasi langsung kegiatan praktik komputer yang dilaksanakan mahasiswa yang berlangsung dalam kegiatan penelitian dalam Proses Belajar Mengajar. Teknik ini dilakukan untuk mengetahui sikap mahasiswa dalam pembelajaran aktif dalam Proses Belajar Mengajar dengan model pembelajaran Problem Solving.

\section{Indikator Kinerja}

Indikator kinerja pada model pembelajaran pada TIK oleh mahasiswa sebagai berikut.

Tabel 3. Indikator Kinerja

\begin{tabular}{|c|c|c|c|c|}
\hline No. & Indikator Kinerja & Baseline & $\begin{array}{c}\text { Target } \\
\text { Tengah } \\
\text { (Tahap II) }\end{array}$ & $\begin{array}{c}\text { Target } \\
\text { Akhir } \\
\text { (Tahap } \\
\text { III) }\end{array}$ \\
\hline 1. & $\begin{array}{l}\text { Kekompakan masing-masing kelompok tutuor } \\
\text { sebaya dalam menyelesaikan tugas-tugas. }\end{array}$ & - & $25 \%$ & 75 \\
\hline 2. & $\begin{array}{l}\text { Kemampuan mengoperasionalkan software } \\
\text { Microsoft Word. }\end{array}$ & - & $25 \%$ & 75 \\
\hline 3. & $\begin{array}{l}\text { Kemampuan mengoperasionalkan software } \\
\text { Microsoft Excel }\end{array}$ & $5 \%$ & $50 \%$ & 75 \\
\hline 4. & $\begin{array}{l}\text { Kemampuan mengoperasionalkan software } \\
\text { Microsoft Powerpoint }\end{array}$ & $5 \%$ & $50 \%$ & 75 \\
\hline 5. & $\begin{array}{l}\text { Persentase mahasiswa yang dapat menyelesaikan } \\
80 \% \text { tes standar matakuliah }\end{array}$ & $20 \%$ & $40 \%$ & $60 \%$ \\
\hline 6. & Persentase mahasiswa yang mendapat nilai akhir & $20 \%$ & $40 \%$ & $60 \%$ \\
\hline
\end{tabular}


A

Sumber : Dosen Pengampu Matakuliah TIK

HASIL DAN PEMBAHASAN

Hasil Implementasi

Kegiatan pembelajaran matakuliah Teknologi Informasi dan Komunikasi (TIK), sebelum perkuliahan dilaksanakan tim peneliti (dosen mata kuliah) merumuskan perangkat pembelajaran berupa kontrak kuliah dan Rancangan Program Pengajaran/RPPS. Setelah itu Tim peneliti membuat perangkat pembelajaran berdasarkan kategori yang dibutuhkan dalam kegitan proses pembelajaran matakuliah matakuliah Teknologi Informasi dan Komunikasi (TIK).

Matakuliah Teknologi Informasi dan Komunikasi (TIK), berlangsung selama satu semester dengan 16 (enam belas) kali pertemuan. Dari enambelas kali pertemuan kegiatan penelitian teaching grant dilaksanakan dalam 4 kali pertemaun, yang telah dilaksanakan pada bulan Agustusi sampai November 2017.

Adapun hasil implemtasi penelitian yang telah dilaksanakan adalah sebagai berikut :

\section{Tahap Persiapan}

Pada tahapan persiapan ini dosen pengampu mata kuliah (peneliti) mempersiapkan unsur materi pembelajaran atau perangkat pembelajaran antara lain Kontrak Perkuliahan dan Rencana Pembelajaran Semester (RPS) yang sifatnya masih konvensional. Kemudian, dosen memberikan petunjuk tugas kepada mahasiswa untuk mencari informasi sebanyak-sebanyaknya

tentang pengoperasian microsoft word, microsoft excel, microsoft powerpoint. Selanjutnya dosen pengampu (peneliti) mempersiapkan peralatan penelitian demikian halnya dengan mahasiswa ditugaskan mencari bahan bacaan yang berkaitan dengan mata kuliah tersebut, kemudian menjelaskan prosedur/sistimatika lapangan yang dilakukan pada matakuliah Teknologi Informasi dan Komunikasi (TIK)

Pada tahap persiapan disusun jadwal dan pembagian kerja bagi tim dosen Matakuliah Teknologi Informasi dan Komunikasi (TIK). Persiapan dilakukan pada awal bulan Agustus 2017. Pre tes dirancang dengan tujuan untuk mengetahui sejauh mana pemahaman mahasiswa terhadap kemampuan awal mahasiswa. Dilihat dari hasil pre-tes, banyak sekali mahasiswa yang asal-asalan menjawab pertanyaan yang diberikan, dan mereka kurang semangat serta kurang antusias untuk mengerjakannya. Banyak mahasiswa yang pasif dan tidak mengembangkan kemampuan yang dimilikinya. Hal ini dapat dilihat dari ketidak siapan mereka dalam mengikuti kegiatan belajar mengajar. Pada saat mengerjakan pre-tes, mahasiswa kurang begitu semangat, dan isi jawabannya masih ada yang kosong atau hanya separuh yang dijawab, tidak secara keseluruhan. Hasil nilai persentase dapat dilihat pada tabel 4 berikut:

Tabel 4. Distribusi Skor Pre-Tes Matakuliah Teknologi Informasi dan Komunikasi (TIK)

\begin{tabular}{|c|c|c|c|c|c|}
\hline \multirow[t]{2}{*}{ No } & \multirow{2}{*}{\multicolumn{3}{|c|}{$\begin{array}{c}\text { Kategori } \\
\text { Nilai }\end{array}$}} & \multicolumn{2}{|c|}{ Jumlah Mahasiswa } \\
\hline & & & & \multirow[t]{2}{*}{$\mathrm{F}$} & \multirow{2}{*}{$\begin{array}{c}\% \\
0.00\end{array}$} \\
\hline 1 & $90-100$ & A & (Sangat Kompeten) & & \\
\hline 2 & $80-89$ & $B$ & (Kompeten) & 4 & 13,79 \\
\hline 3 & $70-79$ & $\mathrm{C}$ & (Cukup Kompeten) & 10 & 34,48 \\
\hline 4 & $0-69$ & $E$ & (Tidak Kompeten) & 15 & 51,72 \\
\hline \multicolumn{4}{|c|}{ Jumlah } & 29 & 100.00 \\
\hline
\end{tabular}


Setelah dilakukan pre-test, selanjutnyapeneliti menjelaskan kepada mahasiswa pada saat proses pembelajaran dilaksanakan agar mahasiswa mengetahui tentang bagaimana skenario pelaksanaan ini dilakukan. Dari aktivitas kegiatan pada tahap ini dosen/tim peneliti menjelaskan prosedur/sistematika yang dilakukan dilapangan kepada kelompok mahasiswa yang sudah dibagi kedalam 5 (lima) kelompok dan memaparkan bentuk permasalahan yang harus diamati oleh mahasiswa pada saat melakukan pembelajaran. Adapun permasalahan yang harus di amati oleh tiap kelompok adalah : (1) penggunakan komputer secara umum baik perangkat keras maupun perangkat lunak, (2) penggunakan fitur sistem operasi Windows, (3) Internet sebagai alat komunikasi dan informasi secara efektif dan efesien, (4) perangkat lunak office: microsoft word, microsoft excel, microsoft powerpoint., (5) hambatan-hambatan dalam pengoperasian komputer. Dosen/Tim Peneliti menyampaikan teoriteori yang berhubungan dengan kajian yang diamati oleh kelompok mahasiswa.Dosen/Tim Peneliti kemudian menyampaikan permasalahan yang berkembang saat ini terkait teknologi informasi dan komunikasi.

\section{Tahap Persiapan Praktikum}

Hasil penilaian pada persiapan praktikum untuk kelompok I yaitu nilai $A$ sebanyak 1 orang, sedangkan yang memperoleh nilai $B$ sebanyak 1 orang, dan Nilai C sebanyak 4 orang. Jumlah mahasiswa dalam kelompok I sebanyak 6 orang dan nilai rata-rata kelompok sebesar 81,17 .

Hasil penilaian pada persiapan praktikum untuk kelompok II, nilai B sebanyak lorang dan nilai $C$ sebanyak 5 orang. Jumlah mahasiswa dalam kelompok II sebanyak 6 orang dan nilai rata-rata kelompok sebesar 78,67.

Hasil penilaian pada persiapan praktikum untuk kelompok III, nilaiB sebanyak 2 orang, nilai $C$ sebanyak 4 orang. Jumlah mahasiswa dalam kelompok III sebanyak 6 orang adapaun nilai ratarata kelompok sebesar 80,07.

Hasil penilaian pada persiapan praktikum untuk kelompok IV nilai $A$ sebanyak 1 orang, sedangkan yang memperoleh nilai $B$ sebanyak 2 orang, dan $C$ sebanyak 3 orang. Jumlah mahasiswa dalam kelompok IV sebanyak 6 orang dan nilai rata-rata kelompok sebesar 81,33.

Hasil penilaian pada persiapan praktikum untuk kelompok $V$ nilai $B$ sebanyak 2 orang, sedangkan nilai $C$ sebanyak 3 orang. Jumlah mahasiswa dalam kelompok sebanyak 5 orang, dengan nilai rata-rata kelompok sebesar 82,20 .Selanjutnya hasil nilai komulatif kelompok pada tahap persiapan praktikum adalah sebagai berikut.

Rata-rata nilai mahasiswa pada tahap pra-praktimum adalah 80,69 dan dari hasil kegiatan yang telah dilaksanakan dapat dianalisa yaitu berdasarkan hasil observasi dapat dijelaskan hambatan pada tahap persiapan ini adalah

1. Keterlibatan dalam kerja kelompok terlihat bahwa hanya sebagian mahasiswa tidak aktif dan kurang berpartisipasi dalam menyelesaikan tugas kelompok.

2. Tanggungjawab dalam kerja kelompok, terlihat hanya sebagian mahasiswa yang memberikan ide dan pendapat untuk membantu menyelesaikan tugas kelompok.

3. Kepercayaan dalam kerja kelompok masih rendah, hal terlihat ketika diminta dosen menyelesaikan tugas kelompok hanya beberapa mahasiswa yang termasuk dalam kategori aktif.

Dengan demikian keberhasilan yang dicapai dari aktivitas kegiatan pada tahap persiapan ini masih tergolong rendah.

\section{Tahap Pelaskanaan Praktikum Komputer}

Pada tahapan ini mahasiswa melakukan praktikum komputer tentang :

1. Microsoft word merupakan software pengolah kata yang sangat 
bermanfaat dalam aplikasinya untuk: membuat surat, laporan, dengan aneka font dan layout yang ada. Lembar kerja atau halaman utama tersebut langsung bisa digunakan untuk mengerjakan berbagai pekerjaan yang berhubungan dengan aplikasi software Microsoft word.

Langkah-langkah praktikum Microsoft word adalah sebagai berikut :
a. Mulai Menjalankan MS-Word
b. Operasi Dasar.
c. Melakukan Editing dan
Formatting Sederhana
d. Mencetak Dokumen

2. Microsoft Excel merupakan software pengolah data yang mencakup: membuat, menyimpan dan membuat workbook, memasukkan tipe data yang berbeda-beda, menghitung dengan menggunakan rumus dan fungsi, menyisipkan grafik, dan lain-lain.

Langkah-langkah praktikum

Microsoft excel adalah sebagai berikut :

Mengenali menu, membuat,

membuka dan menyimpan file

a. Mengenal Bagian-bagian lembar sebar

b. Membuat Buku Kerja Baru

c. Menyimpan Buku Kerja

d. Membuka Buku Kerja yang

Pernah Disimpan

e. Menutup Lembar Sebar

f. Editing Sederhana

g. Menggunakan Rumus dan Fungsi

h. Mencetak Buku Kerja

3. Micorosoft Power Point adalah program aplikasi untuk membuat pre-sentasi secara elektronik yang handal. Presentasi PowerPoint dapat terdiri dari teks, grafik, objek gambar, clipart, movie, suara, dan objek yang dibuat program lain. Program ini pun dapat dicetak secara langsung menggunakan kertas atau dengan menggunakan transparansi untuk kebutuhan presentasi melalui overhead, serta dapat dicetak untuk ukuran slide film. Apabila dibutuhkan, dapat dibagikan kepada audiens sebagai bahan pendukung dalam presentasi.

Langkah-langkah praktikum Microsoft power point adalah sebagai berikut
a. Mengoperasikan Microsoft Power Point
b. Membuat, Membuka, Menyimpan dan Mencetak Presentasi
c. Melakukan Editing Sederhana
d. Design / Layout
e. Memberikan Efek pada Slide
f. Menjalankan Presentasi
g. Mencetak File Presentasi
Dari pelaksanaan pada tahap lapangan ini dapat diperoleh hasil evaluasi seperti tabel dibawah ini :

Hasil penilaian dari tahap praktikum untuk kelompok I yaitu nilaiB sebanyak 5 orang, sedangkan nilai $C$ sebanyak 1 orang. Jumlah mahasiswa dalam kelompok I sebanyak 6 orang dan jumlah rata-rata nilai kelompok sebesar 82,50

Hasil penilaian dari tahap praktikum untuk kelompok II, nilai B sebanyak 6 orang dengan jumlah mahasiswa dalam kelompok II sebanyak 6 orang dan jumlah rata-rata nilai kelompok sebesar 83,17.

Hasil penilaian dari tahap praktikum untuk kelompok III nilai A sebanyak 1 orang, sedangkan yang memperoleh nilai $B$ sebanyak 5 orang. Jumlah mahasiswa dalam kelompok III sebanyak 6 orang dan nilai rata-rata kelompok sebesar 84,00.

Hasil penilaian dari tahap praktikum untuk kelompok IV, nilai A sebanyak 1 orang dan nilai B sebanyak 5 orang. Jumlah mahasiswa dalam kelompok IV sebanyak 8 orang dengan nilai rata-rata kelompok sebesar 85,33.

Hasil penilaian dari tahap praktikum untuk kelompok $V$, Nilai A sebanyak 1 orang, sedangkan nilai B sebanyak 3 orang dan nilai $C$ sebanyak 1 orang. Jumlah mahasiswa dalam kelompok $\mathrm{V}$ sebanyak 5 orang dan nilai rata-rata 
kelompok sebesar 84,80 . Selanjutnya hasil Nilai komulatif kelompok pada tahap praktikum adalah sebagai berikut.

Rata-rata nilai mahasiswa pada tahap praktimum adalah 83,76 dan dari hasil kegiatan yang telah dilaksanakan dapat dianalisa yaitu berdasarkan hasil observasi dapat dijelaskan hambatan pada tahap praktikum ini adalah

1. Keterlibatan dalam kerja kelompok terlihat bahwa sebagian besar mahasiswa terlibat aktif dan berpartisipasi dalam menyelesaikan tugas kelompok.

2. Tanggungjawab dalam kerja kelompok, terlihat hampir semua sebagian mahasiswa yang memberikan ide dan pendapat untuk membantu menyelesaikan tugas kelompok.

3. Kepercayaan dalam kerja kelompok mulai tinggi, hal terlihat ketika diminta dosen menyelesaikan tugas kelompok sebagian mahasiswa termasuk dalam kategori aktif.

\section{Tahap Pasca Praktikum Komputer}

Dari Pelaksanaan pada tahapan pasca praktikum ini dapat diperoleh hasil evaluasi :

Hasil penilaian dari tahap pasca praktikum untuk kelompok I yaitu mahasiswa mendapatkan nilai $A$ sebanyak 3 orang, nilai $B$ sebanyak 3 orang.Jumlah mahasiswa dalam kelompok I sebanyak 6 orang dan jumlah rata-rata nilai kelompok sebesar 87,33.

Hasil penilaian dari tahap pasca praktikum untuk kelompok II, nilai $A$ sebanyak 2 orang, nilai B sebanyak 4 orang. Jumlah mahasiswa dalam kelompok II sebanyak 6 orang dan nilai rata-rata kelompok sebesar 86,33.

Hasil penilaian dari tahap pasca praktikum untuk kelompok III, nilai $A$ sebanyak 2 orang, dan nilai B sebanyak 3 orang. Jumlah mahasiswa dalam kelompok III sebanyak 6 orang dan nilai rata-rata kelompok sebesar 86,83.
Hasil penilaian dari tahap pasca praktikum untuk kelompok IV nilai $B$ sebanyak 6 orang. Jumlah mahasiswa dalam kelompok IV sebanyak 6 orang dengan nilai rata-rata kelompok sebesar 83,83 .

Hasil penilaian dari tahap tahap pasca lapangan untuk kelompok $V$, nilai $A$ sebanyak 4 orang dan nilai $B$ sebanyak 1 orang. Jumlah mahasiswa dalam kelompok $V$ sebanyak 5 orang dengan nilai rata-rata kelompok sebesar 89,80 Selanjutnya hasil Nilai komulatif kelompok pada Tahap pasca praktikum adalah sebagai berikut.

Berdasarkan perolehan nilai mahasiswa pada kegiatan tahap ini diperoleh rata-rata nialai kelompok mahasiswa sebesar 86,82 memiliki peningkatan dari tahap sebelumnya. Hal ini menunjukkan kualitas mahasiswa semakin meningkat dari masing-masing tahapan.

Selanjutnya pada tahapan setelah pelaksanaan latahapan ini dilakukan post test untuk mengukur kemampuan siswa setelah dilakukan pembelajaran dengan beberapa model. Dari hasil post test yang dilakukan, dapat dilihat terjadi penginkatan yang cukup signifikan dari awalnya hanya $14(48,27 \%)$ orang yang lulus, namun saat pengukuran kompetensi di akhir dapat dilihat seluruh mahasiswa mampu menyelesaikan pembelajaran dengan tuntas.

\section{Pembahasan}

Hasil belajar mahasiswa dengan
penggunaan metode pembelajaran
konvensional dengan model tutur sebaya
Dilihat dari hasil nilai pre-tes terlihat bahwa banyak sekali mahasiswa yang asal-asalan menjawab pertanyaan yang diberikan, dan mereka kurang semangat serta kurang antusias untuk mengerjakannya.Banyak mahasiswa yang pasif dan tidak mengembangkan kemampuan yang dimilikinya. Hal ini dapat dilihat dari ketidak siapan mereka dalam mengikuti kegiatan belajar mengajar. Pada saat mengerjakan pre-tes, mahasiswa kurang begitu semangat, dan isi 
jawabannya masih ada yang kosong atau hanya separuh yang dijawab, tidak secara keseluruhan, hasilnya adalah 51,72 persen mahasiswa mendapat nilai E, 34,48 persen mahasiswa mendapat nilai C dan 13,79 persen mahasiswa mendapat nilai B. (gambar 2).
Nilai Metode Konvensional

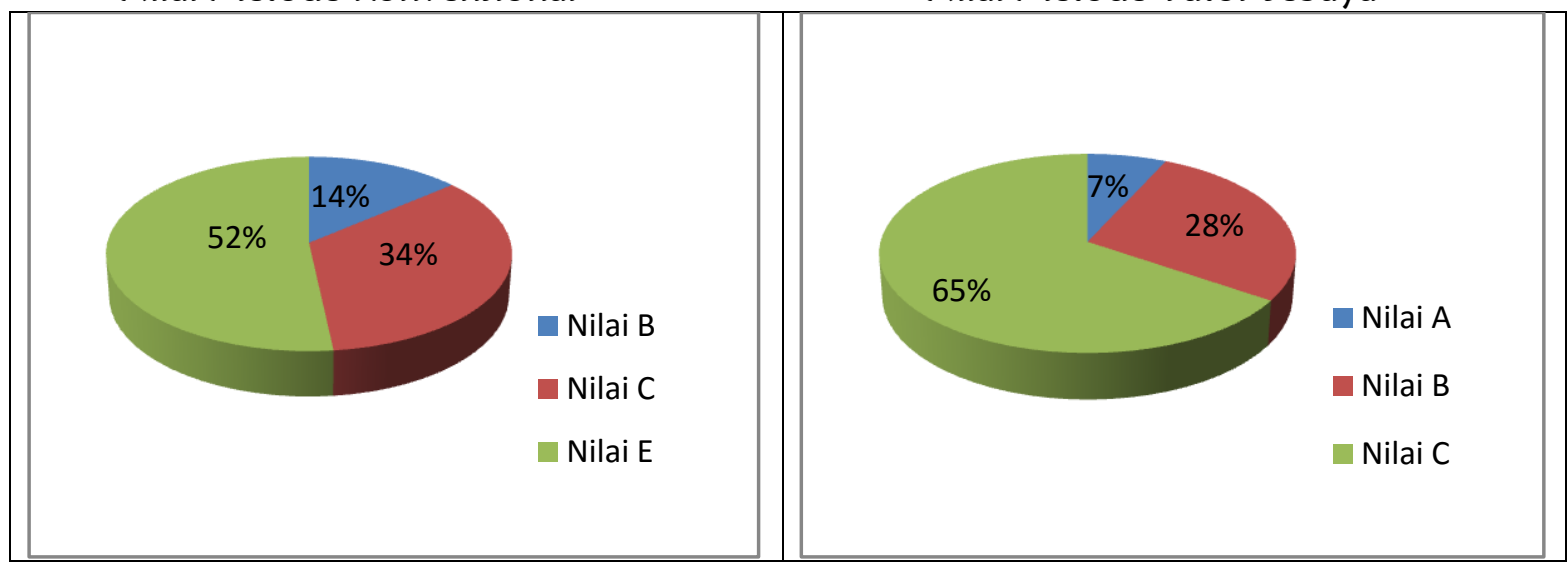

Gambar 2. Perbandingan Nilai Konvensional dan Tutor Sebaya

Komputer Mata Kuliah Teknologi Informasi dan

Komunikasi (TIK)
Model pembelajaran berbasis masalah atau tutor sebaya dilakukan sejak pra-lapangan, yang mana pada tahap pralapangan ini mahasiswa dituntut untuk melakukan serangkaian mempersiapkan bahan pendukung kegiatan praktikum dan mencari berbagai teori melalui media Internet. Dari pelaksanaan pembelajaran pada tahap ini, mahasiswa mengumpulkan secara lengkap data-data yang dibutuhkan, hasilnya adalah 6,90 persen mahasiswa mendapat nilai $A, 27,59$ persen mahasiswa mendapat nilai $B$ dan 65,52 persen mahasiswa mendapat nilai $C$.

\section{Peningkatan Kualitas Mahasiswa Melalui Praktek Tutor Sebaya}

Hasil belajar mahasiswa pada tahap pra praktikum rata-rata nilai mahasiswa 80,69 dengan komposisi nilai $(A=6,9 \%$, $\mathrm{B}=27,59 \%$ dan $\mathrm{C}=65.51, \%)$, tahap praktikum nilai rata-rata mahasiswa 83,76 dengan komposisi nilai $(\mathrm{A}=10,34 \%, \mathrm{~B}=$ $82,76 \%$ dan nilai $C=6,90 \%$ ) dan tahap pasca praktikum memperoleh nilai ratarata 86,82 dengan komposisi nilai $(\mathrm{A}=$ $41,38 \%, B=58,62 \%)$. Hasil ini menunjukkan jumlah mahasiswa yang memiliki nilai yang tinggi semakin meningkat (Gambar 3).
Tahap Persiapan Praktikum

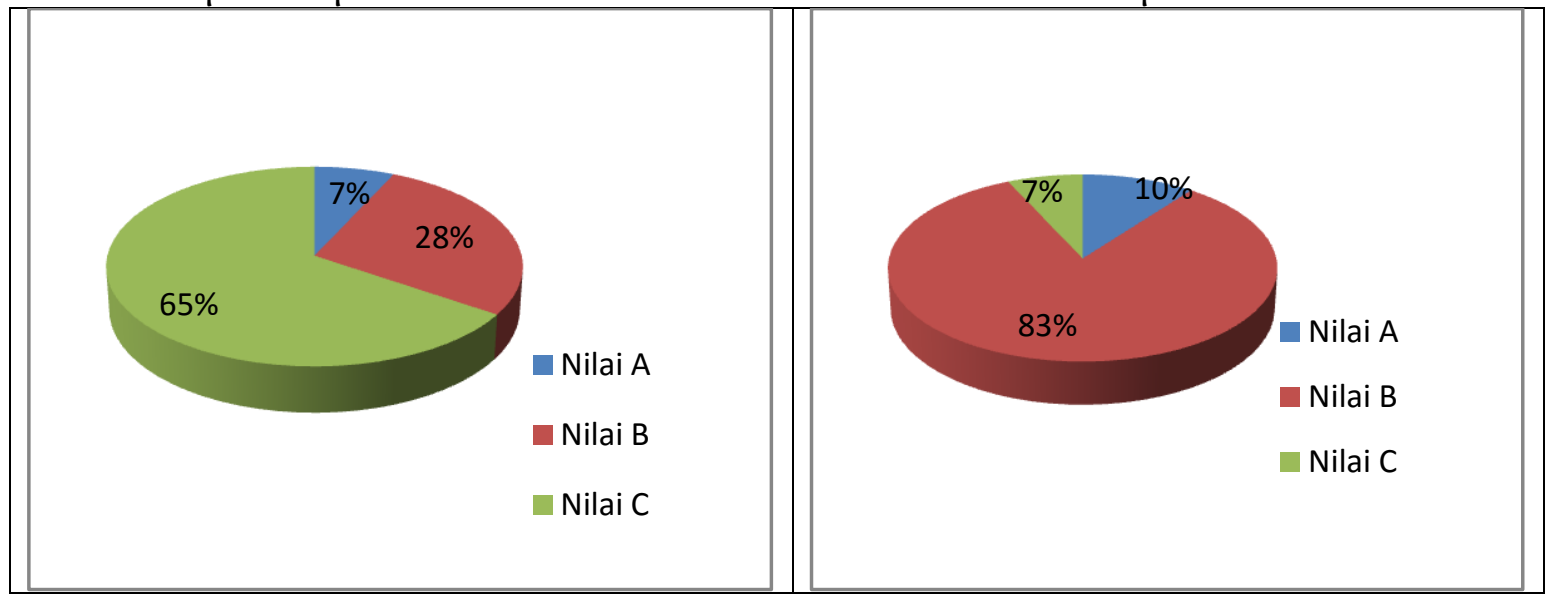

Tahap Praktikum 


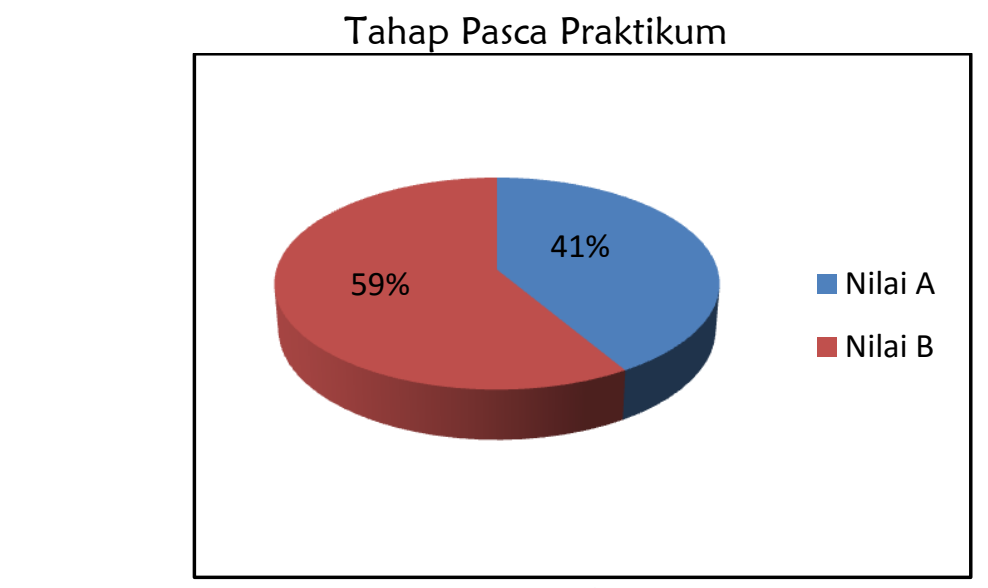

Gambar 3. Perbandingan Nilai Tahap Persiapan Pratikum,

Tahapan Praktikum dan Tahap Pasca Praktikum Mata Kuliah

Teknologi Informasi dan Komunikasi (TIK).

KESIMPULAN DAN SARAN

\section{Kesimpulan}

1. Penerapan model pembejaran berbasis praktikum dalam matakuliah Teknologi Informasi dan Komunikasi dapat meningkatkan kualitas pembelajaran pada mahasiswa di Semester I

2. Pengintergasian IT melalui e-learning dapat dilakukan dalam pembelajaran pada matakuliah Teknologi Informasi dan Komunikasi melalui penugasan dalam bentuk data digital yang dikirimkan melalui email, dan pemanfaatan internet sebagai sumber referensi.

3. Adanya peningkatan prestasi belajar mahasiswa adalah mulai dari kemampuan awal mahasiswa hanya $49,27 \%$ yang dinyatakan lulus, setelah dilakukan inovasi pembelajaran melalui praktek lapangan maka seluruh mahasiswa dinyatakan lulus.

Saran

a. Dengan adanya model pembelajaran tutor sebayaini diharapkan dapat memotivasi mahasiswa dalam pengembangan praktikum.

b. Melalui penerapan model pembelajaran tutor sebayaini diharapkan minat belajar mahasiswa menjadi tinggi khususnya dalam kegiatan praktikum

c. Model pembelajaran tutor sebayadiharapkan dapat membantu dosen melakukan inovasi pembelajaran dan membuka peluang melakukan kolaborasi atau kerjasama dengan jurusan lain dalam pengembangan model pembelajaran.

\section{DAFTAR PUSTAKA}

Arikunto, dkk. 2006. Penelitian Tindakan Kelas, Jakarta : PT Bumi Aksara.

\section{Akrom, 2008, Penerapan Metode Tutor Sebaya dalam upaya mengoptimalkan pembelajaran mata pelajaran KKP. Alamat Web http://smkswadayatmg.wordpress.c om/ xmlrpc.php. diakses 25 Pebruari 2008}

Ginting, E. S., \& Pinem, K. (2012). Upaya Meningkatkan Aktivitas dan Hasil Belajar Siswa Pada Materi Hakekat Geografi dengan Menggunakan Model SQ3R di Kelas X SMA RK Delimurni Bandar Baru TA 2011/2012. JURNAL GEOGRAFI, 4(1), 43-54. 
Jawahir A. 2003, Model Pembelajaran Pemecahan Masalah Matematika dengan Bantuan Tutor Sebaya di Sekolah Menengah Umum Banda Aceh, Tesis, PPSUPI Bandung, Tidak diterbitkan.Supriadi D, Dr, 1994, Kreativitas,

Khasanah, Noor Eva 2009. Implementasi Metode Tutor Sebaya Dapat Meningkatkan Prestasi Belajar dan Motivasi Mahasiswa Diploma IV Reguler Semester I. S2.Thesis. Universitas Pendidikan Indonesia, Bandung

Marjohan, Guru SMA Negeri 3 Batusangkar, Tinggalkanlah metode konvensional,http://groups.yahoo.c om/grouppakguruonline/message/ 3495,12 September 2008

Nababan, G. L. (2012). Perbedaan Hasil Belajar Siswa Dengan Menggunakan Model Konvensional dan Model Pembelajaran Kooperatif Tipe STAD Pada Materi Biosfer Kelas Xi IPS SMA Negeri 1 Pancur Batu. Tunas Geografi, 1(1), 1-13.

Rustam dkk, 2004, Penelitian Tindakan Kelas, Direktorat Pembinaan Pendidikan dan Ketenagaan Perguruan Tinggi Direktorat Jenderal Pendidikan Tinggi Departeman Pendidikan Nasional, Jakarta

Suwanda.D, 2007.Diktat Belajar Komputer jilid 3\&4. http://smkswadayatmg. wordpress.com/xmlrpc.php, 20 Juli 2008

Sudjana N, 1998, Dasar-dasar Proses Belajar Mengajar, Bandung, Sinar Baru, Algensindo.

Supriadi D, 1994, Kreativitas, Kebudayaan dan Perkembangan IPTEK, CV. Alfabeta Bandung.
Sardiman A.M, 1984, Interaksi dan Motivasi Belajar Mengajar, PT. RajaGrafindo Persada, Jakarta

Simamora, E. R., \& Sitompul, M. (2015). Penerapan Model Pembelajaran Kooperatif Think Talk Write (TTW) Untuk Meningkatkan Aktivitas Dan Hasil Belajar Siswa Pada Materi Biosfer Di Kelas XI IPS 2 SMA Negeri 1 Sumbul TA 2013/2014. Tunas Geografi, 4(1), 39-44.

Sirait, M. (2010). KOMUNIKASI SOSIAL MAHASISWA DALAM PENCAPAIAN PRESTASI BELAJAR (Kasus Mahasiswa Jurusan Pendidikan Geografi Fakultas IImu Sosial Universitas Negeri Medan). JURNAL GEOGRAFI, 2(2), 117-124.

Supardi, 2008, Penerapan metode tutor sebaya dapat meningkatkan partisipasi siswa dalam proses pembelajaran matematika di kelas VIII-2 SMP Negeri 101 Jakarta, Makalah kenaikan pangkat, Jakarta

Sukandi, Ujang. 2003. Evaluasi pembelajaran. [Online], Tersedia di Http://muhammadkholik.wordpres s.com/2011/11/08/evaluasipembelaj aran/, diakses tanggal 26 oktober 2016.

Zaini A, 2008, Peningkatan penguasaan matematika siswa melalui kombinasi proses pembelajaan klasikal, kelompok, dan perseorangan, http://media.diknas.go.id/ media/document/5593.pdf, 12 September 2008. 